\title{
The Development of Cooperative Learning Tools with Teams Games Tournament (TGT) Types to Overcome Students' Mathematical Anxiety in Algebraic form Material for The Seventh Grades of Junior High School Students
}

\author{
Syahda Umroh Mahfudhoh \\ Faculty of Mathematics and Science \\ Universitas Negeri Surabaya \\ Surabaya, Indonesia \\ syahda.17070785003@mhs.unesa.ac.id
}

\author{
Dwi Juniati \\ Faculty of Mathematics and Science \\ Universitas Negeri Surabaya \\ Surabaya, Indonesia \\ dwijuniati@unesa.ac.id
}

\author{
Agung Lukito \\ Faculty of Mathematics and Science \\ Universitas Negeri Surabaya \\ Surabaya, Indonesia \\ agunglukito@unesa.ac.id
}

\begin{abstract}
This research was aimed to (1) describe the development the good cooperative learning tools with TGT types on algebraic form material and (2) know the effectiveness of the learning on algebraic form material using TGT to reduce the students' mathematical anxiety. This research was a development research. Development model of the equipment in the current research was an ADDIE, involving Analysis, Design, Development, Implementation, and Evaluation. The subjects of this research were seventh grader of SMP N 1 Rengel-Tuban who experienced mathematical anxiety in learning. In order to investigate the occurrence of students' mathematical anxiety, students were given mathematics anxiety test. The products of this research were lesson plan, worksheets, and an achievement test. The results showed that (1) the develop cooperative learning tools with TGT types have met the good quality criteria as they were valid, practical, and effective, and (2) the learning process applying TGT was effective to overcome students' mathematical anxiety in learning. The effectiveness was known from the ability of the teacher to organize the learning process which was considered good; students' activities in learning were effective; the students' responses are positive; and the classical mastery of the learning reaches by $100 \%$. Moreover, the students' mathematical anxiety problem in learning was reduced by $100 \%$.
\end{abstract}

Keywords-ADDIE model, Cooperative Teaching Equipment, Teams Games Tournament (TGT), Mathematical Anxiety, Algebraic form.

\section{INTRODUCTION}

Mathematics has an important role in life, ranging from simple to very complex roles, as well as contributing to other sciences in everyday life [1]. In teaching mathematics, teachers' creativity become the main factor to make mathematics into interesting topics. Teacher is expected to be able to choose the suitable materials for teaching mathematics based on student condition. The main factor to gain education goal is its teaching and learning process conducted. But until now, mathematics is considered as difficult and boring for students, influencing the quality of learning achievement [2].

Another factor contributes to learning is mathematical anxiety. Math anxiety is the feeling of discomfort and disturbance that some people experience when facing mathematical problems [3]. Many students who suffer from mathematics anxiety lack of confidence in their ability to do mathematics [4, 5] including in the case of proving. In addition, memory performance is disrupted by mathematical anxiety [6]. Under these conditions, the brain has difficulty constructing logical and systematic arguments to prove mathematical statements conclusively.

The use of interesting and joyful teaching model drives the students actively in the teaching and learning process. In this case, cooperative learning is one of the suitable models to gain the goal. In implementing cooperative teaching, the students are distributed in a various group based on academic ability, race, and ethnics. Students with high academic achievement are expected able to be able to help another student to understand the mathematics concept.

One of the various cooperative learning types is cooperative learning with TGT type. TGT was used in academic tournament, quizzes, and individual score, where students as delegation of their team with another who had the same learning achievement [7]. In TGT teaching and learning, students in a group have varying background. Students are expected to understand the lesson, in order the get high achievement in tournament. Students with high achievement is expected to be a tutor for their friends, in order to gain learning goals. Learning activity through tournament is expected to create interesting learning situation. In addition to making students skilled in cooperation, TGT type of cooperative learning is also expected to make students skilled in competence. These competency skills are not possessed by other types of cooperative learning [8]. One way to overcome mathematical anxiety was to learn mathematics comfortably and pleasantly. Thus, TGT type of cooperative learning according to the researchers was suitable for overcoming mathematical anxiety [9]. 
The current research was aimed to developing cooperative teaching equipment with TGT type to overcome students' mathematical anxiety in solving the problem. Based on the aims of the research, the research questions were: (1) how do the development of cooperative with TGT type equipment overcome the students' mathematical anxiety; (2) how do the result of developing cooperative with TGT type teaching equipment able to overcome the students' mathematical anxiety, (3) how about cooperative learning type Teams Games Tournament (TGT) to overcome the mathematical difficulties of students on the subject matter of algebraic form material?

Teams-Games-Tournaments (TGT) was originally developed by David De Vires and Keith Edwards (1972) at the Johns Hopkins University [10]. It is a type of cooperative learning method. The students compete with members of other teams to contribute points to their team score. Students compete in at least three persons "tournament tables" against others with a similar past record in mathematics. Then, procedures change table assignments to keep the competition fair. The winner at each tournament table brings the same number of points to his or her team, regardless of which table; this means that low achievers and high achievers have an equal opportunity for success. High performing teams earn team rewards.

Cooperative learning type TGT is a cooperative learning model which put the students in a learning group consisted of 5-6 students with various gender, race, and ethnics. The students have face-to-face once a week in the tournament with the partner from another team. There will be three students competing with each other. They will answer the same question discussed in their group. Using this way, each student has similar chance to collect score as much as possible. Cooperative learning with TGT type consisted of five stages: class presentation, in-group learning, game, tournament, and award [11].

\section{METHOD}

\section{A. Research Design}

This research was development research. It was called development because this research was intended to produce experiment-based learning materials that met the valid, practical, and effective criteria. The products of this research included a lesson plan, worksheets, and an achievement test.

\section{B. Research Subject}

The subject in the current research was students of grade seven in SMP Negeri I Rengel. The concern of the current research was to develops the lesson plan, worksheets, tournament equipment, and achievement test which was supporting cooperative learning with TGT type for algebraic form material.

\section{The Development Method of Teaching Equipment}

The research was conducted by adopting the ADDIE development model; Analysis, Design, Development, Implementation, and Evaluation [12]. At the stage of the analysis, validation of performance gaps, determination of instructional goals, confirmation of intended audience, identification of required resources, determination of potential delivery systems (including cost estimate), and composition of a project management plan were conducted. In designing stage, equipment was approved based on characteristics of students and appropriate testing methods. The general procedure used in this stage were task inventory, composition of performance objectives, generation of testing strategies, and calculation of investment return. In development stage, learning equipment and research instruments previously arranged based on initial design activities were modified and revised based on input of experts and data obtained from field trials. The activities performed at this stage were experts' assessment, limited testing and field testing. Assessment of experts ranged from content validity, language, display, to equipment conformity with the objectives. The next step was the implementation process. The purpose of this game was to hold learning and involve students. This stage concluded the development conclusions and the final formative evaluation. It was highly recommended that ADDIE used implementation application from formative to summative evaluation. Last stage was evaluation phase. The purpose of the evaluation was to assess the quality of learning.

\section{Techniques and Data Collection Instruments}

Data collected in terms of testing teaching equipment were learning outcomes tests, teaching equipment validation sheets, observation sheets of student activities during learning, observation sheets of teacher skills in implementing learning, diagnostic test, and questionnaires sheets of student responses to teaching equipment. Learning Outcomes Test was used to obtain student learning outcomes data. This test was given before the TGT cooperative learning treatment was given (pretest) and at the end of the learning (posttest) on quadrilateral material. Data obtained from pretest and posttest were then processed to determine validity, reliability, and sensitivity.

The validation sheet was used to collect validation data obtained based on experts' assessment of the learning tools. The validation sheet assessments for all learning tools consisted of 4 score categories; score 1 for "very bad" criteria, 2 for "not good" criteria, 3 for "good" criteria, and 4 for "very good" criteria. This observation sheet was used to obtain data on the ability of teachers during learning using Teams Games Tournament (TGT) model for quadrilateral material. To obtain data on the ability of teachers during learning, observation began from preliminary activities up to closing activities during teaching and learning activities. The assessment consisted of 4 score categories; score 1 for "very good", 2 for "not good", 3 for "good", and 4 for "very good".

Diagnostic test was given to identify student anxiety on mathematics. The questionnaire sheet was used to obtain student response data on the Teams Games Tournament (TGT) learning kit. Students conveyed their responses by giving a checklist in column indicated their opinions on the device and the implementation of learning, then results were analyzed. Questionnaire was used to identify student anxiety in mathematics. Questionnaire was adapted previous study [13]. The questionnaire consisted of 30 questions. 


\section{E. Criteria for good quality learning tools}

TGT type cooperative learning tools were deemed good if they met valid, practical and effective criteria [15]. Learning tools answered these practical questions: (1) Learning tools could be used by teachers who obtain results from assessments during learning, about every aspect in each meeting, including minimum "good" category, (2) Observation results of student activities during learning were found to be active if the activities determined by each aspect were included in the minimal category. Learning tools would be effective if: (1) Students responses to learning tools and learning activities were positive, if the number of respondent students chose positively or gave "Yes" response of at least $70 \%$ for each aspect in question. (2) $80 \%$ limit of students able to complete mathematics could be passed, (3) Students' classical learning completeness was feasible, if at least $80 \%$ of students had more than or at least minimal completeness score, with minimal completeness criteria of 75 .

\section{RESULTS AND ANALYSIS}

\section{A. The Results of the Development of Learning Devices}

The developed cooperative learning tools for Teams Games Tournament (TGT) on algebraic form material for SMP Negeri 1 Rengel-Tuban in this study included Learning Implementation Plan, Student Worksheet, and Learning Outcomes Test. Based on results of validator's assessment on tools developed, in terms of indicators, format, content, and language, all devices were found to have good category and could be used with a little revision. This was indicated by the validator's assessment of Learning Outcomes Test as generally valid, understandable, and slightly revised. A valid and revised learning tool was then tested on a pilot class. Data were obtained during testing of the learning device for three meetings; the ability of teachers to manage learning well, effective student activities, student responses to positive learning, student learning outcomes was found to be in valid, reliable, and sensitive criteria, as well as math anxiety test, in which students were shown to be able to overcome anxiety over math. Based on the criteria of good learning tool, TGT type of cooperative learning device on the algebraic form material met the criteria as a good learning device.

\section{1) Analysis}

The first step in the current study was analysis of students. In this study, we conducted an observation and interview on topics considered as the hardest for students. The result of observation and interview showed that the students found algebraic form topic to be quite hard.

\section{2) Design}

The design stage is designing the product developed, and designing an instrument used to test the quality of the product. the main basics of designing a product that is the purpose of the use of the product, the use of the product produced, and a description of the components of the product and how to use it. The products to be developed are learning tools in the form of lesson plans, student worksheets, learning achievement test, and tournament completeness. Following the development plan for each product:

a) Learning tools in the form of lesson plans

Consists of three meetings. The first meeting about the elements of algebra, the second meeting about the addition and subtraction of algebraic forms, and the third meeting about the multiplication and division of algebraic forms. In this learning tool there are six phases in accordance with the phases of TGT learning. The six phases are present goals and set, present information, organize students into learning teams, assist team work and study, test on the materials, and provide recognition.

b) Student worksheets

Student worksheet consists of three meetings. The components of this student worksheet are learning goals, work instructions, motivation, problems, example problems, and practice questions.

c) learning achievement test

The learning achievement test consists of five questions containing algebraic elements, addition and subtraction of algebraic forms, and multiplication and division of algebraic forms.

d) tournament completeness

Completeness of the tournament consists of a question card and answer key. The material used is in accordance with indicators of competency achievement.

3) Development

Product development based on the design or product framework that has been prepared at the design stage. Learning tools that have been developed are then validated by expert lecturers using instruments that have been previously validated. This activity aims to determine the feasibility and quality of the products produced. Furthermore, improvements are made to the learning device products that are produced according to the input and direction of the validator.

a) Development of learning tools

In developing learning tools, the compiler uses Permendikbud number 37 of 2018 as a reference to the principles and components of learning tools. Each learning tool developed contains three stages, namely opening, core, and closing. The learning steps are carried out in accordance with the TGT cooperative learning steps. Learning tools that have been arranged are then validated by expert lecturers.

Learning Implementation Plan 1. The elements of algebraic form

In Learning Implementation Plan 1 the indicators to be achieved are explaining the coefficients, constants, and variables; determine coefficients, constants, and variables; distinguish between similar and non-similar ethnic groups; explain similar tribes and not similar tribes; determine the same ethnic group and not other ethnic group. The approach used is a scientific approach, the learning model used is the TGT cooperative type. The motivation given at the first meeting was that students were shown a video about Mrs. Nina who was buying oranges at a fruit shop. Then during the tournament, the questions given are in accordance with the indicators to be achieved.

Learning Implementation Plan 2. Addition and subtraction of algebraic forms. 
In Learning Implementation Plan 2 the indicators to be achieved are complete the sum in the algebraic form; complete reduction in algebraic forms; and discover the properties of algebraic arithmetic operations. The approach used is a scientific approach, the learning model used is the TGT cooperative type. The motivation provided at this second meeting was to play a video about Spongebob and Mrs. Puff who would buy a pen and pencil. Then during the tournament, the questions given are in accordance with the indicators to be achieved.

Learning Implementation Plan 3. Multiplication and division of algebraic forms.

In Learning Implementation Plan 3 the indicators to be achieved are completing multiplication on algebraic forms; complete the division in algebraic form; and solving contextual problems related to multiplication and division operations in algebraic forms. The approach used is a scientific approach, the learning model used is the TGT cooperative type. Then during the tournament, the questions given are in accordance with the indicators to be achieved.

b) Development of student worksheets

The development of student worksheets is carried out by considering aspects of format, linguistic aspects, and content aspects. Student worksheets that have been arranged are then validated by expert lecturers. Topics in student worksheets which were generated were divided into three meetings:

Student Worksheets 1. The elements of algebraic form.

In Student Worksheets 1, an illustration is presented that there are 2 baskets containing the same oranges and 5 oranges. Lots of oranges in a basket, can be assumed by something called a variable. The number of baskets is called the coefficient, and oranges that are not in the basket can be called constants. In addition, it also describes similar and non-similar tribes. At the end, several questions are presented and students are asked to work on them in groups.

Student Worksheets 2. Addition and subtraction of algebraic forms.

In Student Worksheets 2, provided an illustration of the conversation between Mr. Ahya and Mr. Ubay who were buying books at a bookstore. Then Mr. Ahya gave the book he had bought to his children. From this illustration, two algebraic forms of operations can be carried out, namely addition and subtraction. The terms that can be added up or subtracted are only the same terms. In addition, also presented a table of the addition properties of algebraic forms, students are asked to complete the table. At the end, several questions are presented and students are asked to work on them in groups.

Student Worksheets 3. Multiplication and division of algebraic forms.

In student worksheets 3, students are reminded of the nature of rank in the integer material that was taught in chapter 1 . Then the land illustration is given Mr. Wahib is rectangular in shape with known length and width in algebraic form. Students are asked to determine their breadth. Because the area of a rectangle is length times width, we can use the concept of the multiplication form of algebra in the illustration. To find the length or width, if what is known is breadth, then the concept of algebraic form division can be used. In addition, also presented a table of the multiplication of algebraic forms, students are asked to complete the table. At the end, several questions are presented and students are asked to work on them in groups.

c) Development of tournament completeness

Tournament Card 1. The elements of algebraic form.

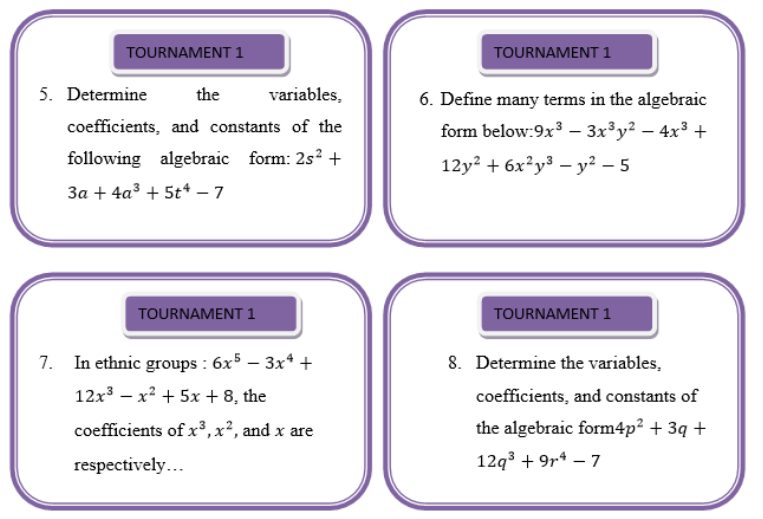

Figure 1. Tournament card 1 number five until eight.

Tournament Card 2. Addition and subtraction of algebraic forms.

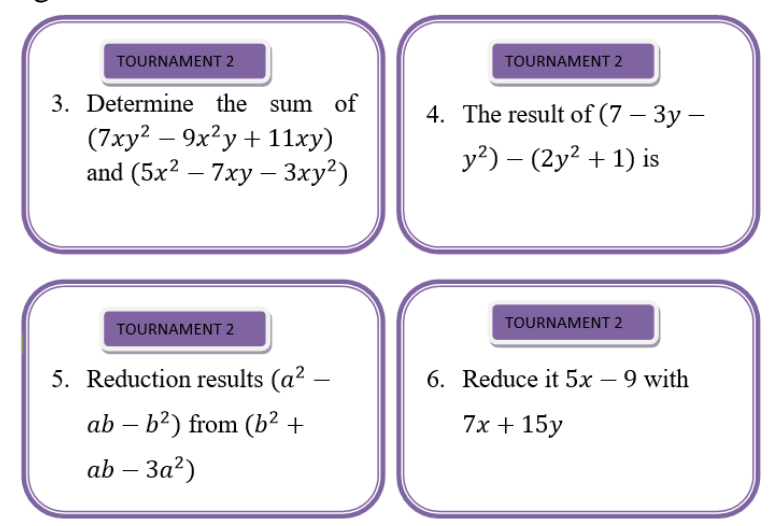

Figure 2. Tournament card 2 number three until six.

Tournament Card 3. Multiplication and division of algebraic forms.

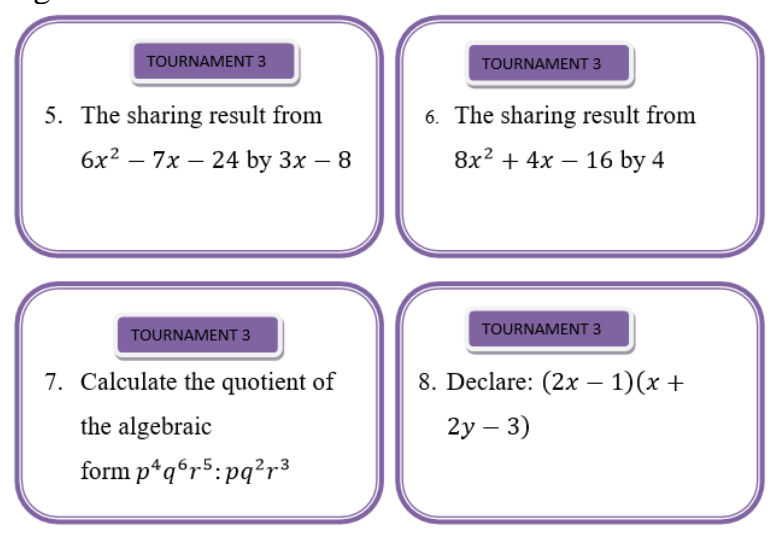

Figure 3. Tournament card 1 number five until eight. 


\section{d) Development of research instruments}

The instrument used in the study includes three aspects, namely the evaluation of validity, practicality, and effectiveness.

\section{4) Implementation}

The lesson plan with cooperative TGT-type approach were used in trial by teacher and students in the class. We first explained the teaching design. Before the implementation phase, the teacher conducted simulation, then we observed implementation and filled the simulation sheet.

\section{5) Evaluation}

In this phase, students were given post-test after implementation of cooperative learning. Questions used during pre- and post-test were same. The result of pre- and post-test were used to measure the effectiveness of teaching and learning model developed. Furthermore, students were asked to fill questionnaire on the idea about teaching and learning developed. The questionnaire was used to measure practical value of model developed. Response of students was used to develop better tools.

\section{RESEARCH RESULT}

\section{B. Learning Effectiveness Test Results}

A good learning tool was implemented in class to describe the effectiveness of TGT type cooperative learning on algebraic form material. Data obtained from the effectiveness test will be discussed below.

\section{Teacher's Ability to Manage Learning}

At the initial, core, and closing activities of each meeting, the teacher's ability reached minimum value of 4 . Teacher enthusiasm was apparent in every TGT-type cooperative learning and teacher was confident in carrying out learning so as to make students eager to learn.

\section{Student Activities during Learning}

Based on student activity criteria, then every aspect for all lesson plans had minimally good category. Student activities during TGT type cooperative learning could be said to be good. In other word, observed student activities during learning for three meetings could be categorized as effective

\section{E. Student Response}

Regarding students' responses to learning kit, analysis showed that $100 \%$ of students gave a positive response to every aspect of the learning kit or to each question in the questionnaire. This meant that the learning devices was received positively by students and the results obtained were as desired. It could be concluded that the TGT cooperative learning device was effective for learning algebraic form material in terms of the students' response criteria to learning.

\section{F. Completeness of Learning Outcomes}

Based on the analysis of students' mastery learning data classically in the TGT type of cooperative learning in algebraic form material during test class, it showed that the learning achievement test was valid, reliable, and sensitive. This was shown by the results of the analysis of the validity of the items where for number $1 r_{x y}=0.4551$ (quite valid), number $2 r_{x y}=0.8201$ (very valid), number $3 r_{x y}=0.6129$ (valid), number $4 r_{x y}=0.6353$ (valid), and number $5 r_{x y}=$
0.7167 (valid). It was also shown by the reliability coefficient, which was $r_{x y}=0.431$ (the reliability of the questions was quite high). Sensitivity value for each item was also found to be sensitive, as indicated by the sensitivity value of item $1 \mathrm{~S}=$, number $2 \mathrm{~S}=0.58$, number $3 \mathrm{~S}=0.52$, number $4 \mathrm{~S}=0.50$, number $5 \mathrm{~S}=0.56$. Thus, it could be said that the TGT cooperative learning device was good and could be applied in algebraic form material learning. Learning was said to be complete if the Learning Outcomes Test score was at least 75 . A total of 32 students (100\%) obtain score of at least 75 . This showed that TGT-type cooperative learning had successfully achieved terms of mastery of learning.

\section{G. Mathematics anxiety of students}

Based on results of mathematics anxiety questionnaire before and after learning, it was shown that $100 \%$ students who initially experienced mathematical anxiety could had finally overcome it. All students had not experienced mathematical anxiety at the end of learning.

\section{H. Student mathematics anxiety data}

The effectiveness of TGT cooperative learning was based on 5 indicators; the ability of teachers to manage effective learning, effectiveness of student activities, positive student responses, completeness of learning outcomes classically, and students' mathematical anxiety overcame. Based on the criteria to achieve learning effectiveness, the learning provided for class implementation was effective, student activities during learning were found to be effective, teacher's ability could manage effective learning, student responded positively, completeness of student learning outcomes were achieved, and student could overcome mathematics anxiety.

\section{CONCLUSIONS}

Based on the results of the discussion in this study, the following conclusions could be drawn; the process of developing Teams Games Tournament (TGT) type of cooperative learning tool on an algebraic form material for Grade VII students of SMP N 1 Rengel-Tuban used ADDIE development model (analysis, design, development, implementation, and evaluation). The development began with analysis. The results of the analysis were used to design draft of learning device at the design stage. Learning tools designed (draft I) were then validated by experts. After being validated by experts, the learning tools were revised according to the experts' recommendations. After all learning tools were found to be valid, we conducted readability test on the worksheet and Learning Outcomes Test. Then, the device was tested on a trial class. The data obtained in the pilot class was analyzed to find out whether the learning devices developed were of good quality or not. The results of the development of learning tools were in the form of Learning Implementation Plans, Student Worksheets, and Learning Outcomes Test. All learning tools produced could be said to be good if: (1) The tools could be used by teachers who obtain results from assessments during learning settings on every aspect in each meeting, including minimal good category, (2) observed student activities during learning were announced to be active if the activities determined by each aspect had the minimal category, (3) students' responses to learning tools and learning activities were positive if the number of 
respondent students chose positively or gave "Yes" response was at least $70 \%$ for each aspect in question, (4) $80 \%$ limit of students who could complete mathematics, (5) Students' classical learning completeness was feasible; at least $80 \%$ of students obtain classical learning completeness with minimum score of 75. TGT-type cooperative learning was found to be effective for teaching algebraic form material to VII grade students of middle school because it met the specified learning effectiveness criteria.

\section{ACKNOWLEDGMENT}

The authors would like to thank: (a) Postgraduate program of Mathematics education, Universitas Negeri Surabaya, Indonesia that support the research to be conducted and implemented well, and (2) junior high school of SMP N 1 Rengel-Tuban.

\section{REFERENCES}

[1] U. Sumarmo, Pembelajaran Matematika untuk Mendukung Pelaksanaan Kurikulum Berbasis Kompetensi. Laporan Penelitian. FPMIPA UPI Bandung: Tidak diterbitkan, 2004.

[2] M. A. A. Mutawah, "The Influence of Mathematics Anxiety in Middle and High School Students Math Achievement in International Education Studies," Canadian Cent. Sc. Edu., vol. 8, no. 11, pp. 239252, 2015.

[3] M. Kargar, R. A. Tarmizi, and S. Bayat, Proced. Soc. Behav. Sc., vol. 8, pp. 537-542, 2010.

[4] K. V. Pantaleon, V. S. Kurnila, M. Tamur, and F. Nendi, Prosiding Seminar Nasional Matematika dan Aplikasinya, pp. 134 - 141, 2017.
[5] M. H. Ashcraft and E. P. Kirk, J. Exp. Psych.: General, vol.130, no. 2, pp. $224-237,2001$

[6] R. E. Slavin, Cooperative Learning. Teori, Riset dan Praktik, edisi terjemahan, Bandung: Nusa Media, 2005.

[7] M. Nur and Wikandari, Pengajaran Berpusat kepada Siswa dan Pendekatan Konstruktivis dalam Pengajaran, Surabaya: PSMS Program Pascasarjana Unesa, 2000.

[8] E. Freedman, Do You Have Math Anxiety? A Self Test, 2012.

[9] A. Salam, A. Hossain, and S. Rahman, "Effects of using Teams Games Tournaments (TGT) Cooperative Technique for Learning Mathematics in Secondary Schools of Bangladesh," Malaysian On. J. Edu. Tech., vol. 3, no. 3, 2015.

[10] R. E. Slavin, Psikologi Pendidikan, Teori, Riset dan Praktik, edisi terjemahan, Jakarta: PT. Indeks, 1995.

[11] R. M. Branch, Instructional Design: The ADDIE Approach, New York Springer, 2009.

[12] M. Bursal, and L. Paznokas, "Mathematics Anxiety and Preservice Elementary Teachers' Confidence to Each Mathematics and Science," School Sc. Maths., vol. 104, no. 6, pp. 173-180, 2006.

[13] J. Farida, Wilujeng, and Senam, "Developing android-based science instructional media to improve scientific literacy of junior high school students," International Conference on Science Education (ICoSEd), 2018. DOI:10.1088/1742-6596/1006/1/012034

[14] N. Nieveen, "Prototyping to Reach Product Quality," in Design Approaches and Tools in Education and Training, J.V. Akker, R. M. Branch, K. Gustavon, N. Nieveen, and T. Plomp, Dordrecht, Netherland: Kluwe Academic Publisher, 1999. 